\title{
Laberintos de orgullo, de Rosa María Britton: identidad, memoria y escritura en la nueva novela histórica de Centroamérica
}

Dra. Iris Chaves Alfaro ${ }^{i}$, Universidad Nacional

Recibido: 2/07/2013

Aceptado: 20/05/2015

\section{Resumen}

Como una muestra de las propuestas estéticas, literarias e identitarias que ofrece la "nueva novela histórica" de Centroamérica, se pretende hacer una lectura de la novela Laberintos de orgullo, de la escritora panameña Rosa María Britton. Se quiere mostrar los rasgos propios de la nueva novela histórica centroamericana, tanto como las singularidades de la escritura de la región, en relación con la construcción de las identidades, en un contexto reconocido como poblado de diversidades. Cómo piensan y plasman los escritores centroamericanos sus autoimágenes en la "nueva novela histórica", cómo han ideado su historia, sus culturas y sus signos, de qué forman plantean la relación entre la historia y la ficción, es el problema que busca abordar el presente estudio.

\section{Abstract}

\section{Laberintos de orgullo (Labyrinths of Pride), by Rosa María Britton: Identity, Memory and Writing in the New Historical Novel of Central America}

As a simple of the aesthetic, literary and identity proposals offered by the "new historical novel" of Central America, the purpose of this paper is to give a particular reading to the novel Laberintos de orgullo, (Labyrinths of Pride) by the Panamanian writer Rosa María Britton. The objective is to show the particular features of the new Central American historical novel, as well as the singularities of the region's writing in connection to the construction of identities in a context known to be diverse. How the writers think and put into writing their self-images in the "new historical novel", how they have pictured their history, cultures and symbols, in which ways they explicit the relation between history and fiction is the main issue this study aims to approach.

i Iris Chaves es profesora de Literatura Latinoamericana en la Universidad Nacional, en Costa Rica. Tiene un doctorado en literatura latinoamericana, obtenido en la Universidad Nacional, y una maestría en esa misma área, de la Universidad de Costa Rica.
Iris Chaves Alfaro. Laberintos de orgullo, de Rosa María Britton: identidad, memoria y escritura en la nueva novela histórica de Centroamérica. Revista Comunicación. Año 36, vol. 24, núm. 1. Enero - julio, 2015. Tecnológico de Costa Rica. ISSN Impreso: 0379-3974/ e-ISNN: 1659-3820

\section{PALABRAS CLAVE:}

Laberintos de orgullo, Rosa María Britton, novela histórica, novela centroamericana, cultura centroamericana.

\section{KEY WORDS:}

Laberintos de orgullo, Rosa María Britton, novel histórica, Central American novel, Central American culture. 


\section{Quizá yo he creado las estrellas y el sol y la enorme casa, pero ya no me acuerdo}

\section{Jorge Luis Borges, La casa de Asterión}

Desde finales de los años setenta hasta hoy se han publicado en Centroamérica más de cien novelas clasificadas como nuevas novelas históricas, lo que evidencia el interés de los autores por la historia de la región como una forma de reflexión sobre las culturas centroamericanas y sus identidades. Aunque el surgimiento de este tipo de novela se produce en toda América Latina, la novela centroamericana presenta particularidades como el interés por recuperar el legado precolombino y los puntos de anclaje históricos, como la revolución sandinista $y$, en general, las guerras civiles.

La nueva novela histórica ha sido reconocida por la crítica como un subgénero de la "nueva novela latinoamericana", iniciada a partir de la década de los setenta. En ese momento, según Arias (1998):

(...) se registró una explosión de la narrativa producida en Centroamérica, no solo cuantitativa sino también cualitativamente. Aunque este fenómeno fue influenciado por el boom de la literatura latinoamericana, adquirió rasgos característicos propios que sin embargo han sido poco estudiados por la crítica centroamericana.

La producción literaria centroamericana de las décadas comprendidas entre los años sesenta y la actualidad ha encontrado dificultades para ser clasificada. Mientras algunos estudiosos hablan de posmodernidad, otros, como Mackenbach (2004), se preguntan si se trata de una literatura del "pos - pos - boom", por rasgos como la metaficción, la ironía y los juegos con el lenguaje. También se han intentado clasificaciones basadas en tendencias, actitudes y temáticas y, así, se han acuñado categorías como "novela deceptiva" o novela del "desencanto", literatura de migraciones, del cinismo, literatura urbana. Mackenbach (2004) afirma que:

(...) las literaturas centroamericanas contemporáneas se destacan por una gran variedad de formas y estrategias narrativas. Elementos de una literatura light y de la literatura trivial y cursi coexisten con las formas de la literatura de testimonio, construcciones intertextuales altamente artificiales y también procedimientos experimentales, metatextuales y metaficcionales (2004, p.3).

Sin embargo, él mismo reconoce que:

Todavía no tenemos una periodización de estas literaturas que sea convincente científicamente y que respete las diferentes líneas de tradición y las rupturas, las fases y desfases de este proceso literario cultural en el istmo, desde los años sesenta del siglo XX" (Mackenbach, 2004).

A pesar de todas las posibles clasificaciones de la literatura centroamericana de los últimos cincuenta años, por lo que atañe a la novela, la denominación "nueva novela" parece ser único punto de coincidencia de los críticos y teóricos; aunque también en relación con este concepto hay divergencias.

Zavala (1990), en su tesis sobre la "nueva novela" en Centroamérica, reconoce para el período tres direcciones fundamentales:

a. Producción novelístitica que se ajusta los modelos de la "novela del boom" o "nueva novela latinoamericana".

b. Novela de ruptura con la novela tradicional, a partir del testimonio y de la crónica testimonial.

c. Forma que sintetiza las dos anteriores, en especial las tendencias posmodernista y testimonial.

En esta última clasificación se ha ubicado a la "nueva novela histórica" como manifestación de la orientación posmodernista.

En el contexto mencionado surge la nueva novela histórica, la cual presenta una especial relación entre la historia y la ficción. Aunque otros académicos y críticos, como Fernando Aínsa (1937 - ), ya habían dedicado atención a la "nueva novela histórica" y habían propuesto ese nombre, Menton (1993) logra dar a conocer este subgénero. Pero, como lo aclara en el título citado, él se refirió a la nueva novela histórica latinoamericana e ignoró cualquier clasificación de la producción centroamericana. Fue después de la aparición de este texto que la "nueva novela histórica" alcanzó su canonización desde la academia norteamericana: se introdujo en los programas del pensum de varias universidades e importantes editoriales se interesaron por publicar novelas del subgénero; también la mayor parte de los críticos que posteriormente extendieron estudios sobre la "nueva 
novela histórica", tomaron como fundamento los rasgos que Menton definió como características posmodernas del subgénero: ficcionalización de personajes históricos, metaficción, intertextualidad, subordinación de hechos históricos a ideas filosóficas, distorsión de la historia por medio de exageraciones y anacronismos, múltiples interpretaciones de sucesos y personajes y ubicación de los acontecimientos en una época anterior a la del autor.

La manera en que esta novela se legitima, no solo por un largo ciclo de más de treinta años y una vasta producción, sino también por tratarse como un fenómeno de mercado, opacó otras tendencias, otros subgéneros y géneros. Cuando se hace una revisión del universo de la novela en Centroamérica, se puede constatar que la nueva novela histórica aventaja en número a otros tipos de novela. Puede verse como una singularidad de la "nueva novela histórica", respecto de su constitución interna, la síntesis de otras tendencias, géneros y subgéneros y el hecho de centrar su atención en eventos históricos, desde el "cronotopo de Indias", pasando por la Independencia, hasta las guerras civiles y otros hechos.

Después de hacer una revisión de gran cantidad de textos teóricos y críticos sobre la "nueva novela histórica", se puede determinar que la mayoría de los estudios (Arias, 1998) se ha hecho con referencia a textos no centroamericanos, lo cual es comprensible porque, a pesar de lo vasto de la producción y de su importancia institucional,

(...) en el contexto centroamericano, la textualidad surge desde la marginalidad de la marginalidad. El discurso de esta región particular del mundo no solo es marginal con relación a los centros de poder mundial, sino incluso a los pequeños centros de poder marginal: México, Buenos Aires, Sao Paulo" (p. 11).

No se puede obviar que la "nueva novela histórica de Centroamérica se ha seguido publicando hasta el presente y que ha sido lanzada al mercado por editoriales tan importantes como Alfaguara. Por otra parte, nombres como el de Sergio Ramírez y Arturo Arias han dado a conocer este tipo de novela no solo en la región, sino también en el resto de América Latina, los Estados Unidos y Europa.

Importante resulta hacer notar que la "nueva novela histórica" se ha considerado como un tipo de novela que subvierte o se contrapone a la novela histórica tradicional, la cual ha cumplido a lo largo de los años de existencia de la literatura latinoamericana y centroamericana, un papel primordial. Desde la novela histórica romántica hasta la nueva novela histórica se perciben cambios marcados en cada período. Empero, el tratamiento de personajes y sucesos históricos y ficticios relacionados con modelos de autorrepresentación constituye el eje de toda esa escritura.

Aunque se puede hablar de novela histórica realista, romántica, criollista y modernista, hasta antes de finales de los años setenta las novelas de los diferentes períodos y corrientes tenían en común la afirmación de ciertos lugares de la nacionalidad, por ejemplo, un verosímil histórico y la imagen de una nación - Estado.

Algunos investigadores, especialmente los representantes de la academia norteamericana aseguran que la nueva novela histórica desarticula las imágenes de la nación - Estado y reescribe la historia antes escrita por los grupos dominantes. Pero, el entramado de las construcciones de la identidad resulta mucho más complejo. La lectura atenta de una serie de novelas del subgénero histórico motivó, en parte, este estudio, y llevó a formular otras premisas en relación con los planteamientos de la identidad en la "nueva novela histórica", tendiente más bien a mostrar las zonas de impacto, los conflictos en las representaciones y concepciones de nación y de región. Fueron emergiendo reconceptualizaciones como la de "cultura", "familia" y "nación", así como interesantes propuestas políticas, filosóficas y estéticas integradas por el núcleo de las identidades.

Como una muestra de las propuestas estéticas, literarias e identitarias que ofrece la "nueva novela histórica" de Centroamérica, a continuación se pretende hacer una lectura de la novela Laberintos de orgullo, de la escritora panameña Rosa María Britton. Se quieren mostrar los rasgos propios de la "nueva novela histórica" centroamericana y las singularidades de la escritura de la región referentes a la construcción de las identidades, en un contexto reconocido como poblado de diversidades. Particularmente, el problema que busca resolver el presente estudio es cómo piensan y plasman los escritores centroamericanos sus autoimágenes en la "nueva novela histórica", y cómo han ideado su historia, sus culturas y sus signos.

Para ese fin, se escogió como muestra Laberintos de orgullo, por la solidez y la calidad literaria, la integración y síntesis que hace de propuestas de otras novelas y porque presenta una forma de construir las imágenes y cronotopos de la nacionalidad que se reitera en otros textos del mismo tipo en otros países de la región. 
Además, resultó interesante conocer los planteamientos identitarios nacionales y regionales de una novela de un país que históricamente ha sido excluido de la concepción de Centroamérica.

En el análisis se parte del argumento de la novela, el cual tiene importancia en la medida en que arroja una serie de relaciones entre los diferentes componentes, niveles, personajes y acontecimientos que, a la larga, constituyen la manera de asegurar el control del sentido del texto.

\section{EL ARGUMENTO Y EL TÍTULO}

La novela es un diálogo entre Santos Calderón y la doctora Irina Conde. En el presente textual ellos van viajando desde Panamá hacia los Estados Unidos, donde Santos será intervenido quirúrgicamente para tratar de salvar su vida, pues lo aqueja un mal cardíaco. Irina es la psiquiatra de Santos y él le ha pedido que lo acompañe en el viaje. Existe atracción entre ellos. En el trayecto, Santos le cuenta a Irina toda su vida: su infancia, la historia de su madre Misaela, los conflictos de identidad de un niño de origen desconocido y a quien todos señalan por el origen colombiano de su madre, la ausencia de un padre a quien no conoció nunca. Aún siendo niño se relacionó con el Rey Leopoldo III, de Bélgica. Con él y una comitiva recorrió el camino de Balboa hasta el Mar del Sur. De adolescente fue protegido por doña Catalina, una representante de la alta y antigua aristocracia de Panamá, quien lo manda al colegio y luego le consigue una beca en una universidad belga. Santos estudia y viaja por Europa. Regresa a Panamá convertido en un prominente economista, se casa con Patricia, una representante de la alta burguesía del país, procrean un hijo y una hija. Pero de niño había conocido y amado a Luz María. El matrimonio entre Santos y Patricia es solo por conveniencia.

En la autobiografía que Santos le cuenta a Irina inserta los episodios de la historia de Panamá en la época de Noriega y Torrijos. Ese período se conecta con frecuentes alusiones a la figura de Balboa, como un contrapunto de los que él describe como políticos y militares corruptos del presente, agentes del narcotráfico.

Santos mantiene una fría relación con su esposa. Vuelve a encontrarse con Luz María en uno de sus frecuentes viajes a Madrid y mantiene una relación que, aunque ocasional, es muy fuerte. Más adelante, Luz María es asesinada por un militar que la acosaba. Ella, además, era militante de la oposición.
A lo largo de toda la novela se plantea el proyecto de Santos: buscar a su madre, quien había desaparecido pues se había ido a Colombia, a buscar a sus padres. Cuando Santos la encuentra está a punto de morir, pero puede estar con ella el tiempo suficiente como para conocer quién era su padre, su familia y su origen.

De ser un niño muy pobre en el pueblo costero de Chumico, Santos llega a ser un acaudalado profesional, un intelectual que busca la comprensión del papel que la burguesía y la clase intelectual tienen en el destino de su país.

Se desprende de este argumento que hay relaciones familiares, amorosas, políticas y sociales que confluyen en el foco textual de la historia, en este caso específico, de la historia de Panamá. También existen alusiones a Costa Rica como un espacio relativamente seguro y neutral.

Al argumento se le debe agregar el título, como indicador de un movimiento: el laberinto por definición es un espacio formado por calles y encrucijadas, donde quien ingresa en él se confunde y no puede salir o tiene dificultad para hacerlo. Figurativamente se aplica a asuntos intrincados. El título, entonces, se relaciona con la trama, pues Santos, a menudo, a largo de toda la novela, narra sobre el laberinto de su vida, en busca de sí y sus orígenes: los laberintos de orgullo son los que le han impedido aceptar su pasado, su condición y la procedencia de su familia.

Amorosamente también la vida de Santos es un laberinto y la relación con sus hijos, sus amigos y otros familiares se bifurca o multiplica sus caminos.

\section{IDENTIDADES Y SUS REPRESENTACIONES}

Tal y como se apuntó en los primeros párrafos, el objetivo central de este estudio es revelar las coordenadas de identidad que sostienen la propuesta novelesca, de manera que los apartados que siguen constituyen niveles y componentes de una arquitectura de la novela (en palabras de Bajtin -1989-) en ese sentido.

Antes, es preciso acotar que el término identidad es tan complejo que pueden dársele infinidad de definiciones y es un asunto de primer orden en los estudios culturales, artísticos, históricos y filosóficos. Cuanto más se habla de crisis de las identidades en la posmodernidad y en la globalización y mundialización de la cultura, más se crean estrategias para revalorar y recuperar lo que se considera "lo propio". 
Las identidades pueden aprehenderse en el discurso, donde se plasman y legitiman las "realidades" y se delimitan las relaciones con el Otro, por medio de un juego de exclusiones e inclusiones.

Según Anderson (1983), las identidades nacionales se construyen en términos de un imaginario que es construido por la negación, afirmación o subversión de comunidades constituidas por lugares geográficos y fronteras, por categorías temporales (presente - pasado), la nación y otras focalizaciones organizadoras. Puede ser pertinente agregar, con Bajtin (1983), que en esas comunidades se desplaza un tipo de ser humano, movido por ciertos valores que definen la arquitectura moral.

Todos esos elementos entran en la composición de la imagen de la Nación, junto con dos metáforas: la tradición como paradigma y una subjetividad histórica única e individual, las cuales convierten la identidad en una esencialidad o una sustancia. En ese sentido, la modernidad construye la Historia a partir de la recuperación del pasado de forma "exacta" $y$ "verdadera", por parte de un sujeto individual.

Frente a esa perspectiva entonces, se multiplican propuestas contrarias, como las que se refieren a las identidades en la globalización y a la pérdida de la centralidad de la cultura letrada occidental, así como a los "no lugares" tal y como los formula Augé (1994), quien explica que la antropología y la etnología se han ocupado del "aquí" y del "ahora". El "aquí" europeo occidental "adquiere todo su sentido con respecto a un "afuera" lejano, antes "colonial", hoy "subdesarrollado", que han privilegiado las antropologías británica y francesa" (p. 17).

Las muy conocidas "comunidades imaginadas" de las que habla Anderson (1983) se han construido como conjuntos de representaciones preconcebidas y determinadas por la epistemología del colonialismo. Para Augé (1994), la investigación antropológica de la actualidad se diferencia de la del "aquí" y del "ahora" porque asume la existencia del Otro:

Trata de todos los otros: el otro exótico que se define con respecto a un "nosotros" que se supone idéntico (nosotros franceses, europeos, occidentales; el otro de los otros, el otro étnico o cultural, que se define con respecto a un conjunto de otros que se suponen idénticos, un "ellos" generalmente resumido por un nombre de etnia; el otro social; el otro interno con referencia la cual se instituye un sistema de diferencias que comienza por la división de los sexos pero que define también en términos familiares, políticos, económicos, los lugares respectivos de los unos y los otros, de suerte que no es posible hablar de una posición en el sistema (mayor, menor, segundo, patrón, cliente, cautivo ...) sin referencia a un cierto número de otros (pp. 24-25).

Para Augé (1994), en el conjunto de los "no lugares" se incluyen los nuevos espacios de tránsito (no relacionales, no históricos, no identitarios), como los aeropuertos, supermercados, transportes, centros de entretenimiento, entre otros. En cambio, los "lugares" son identificatorios, relacionales e históricos. Entre los "lugares" y los "no lugares" hay una relación de "palimpsesto".

Las identidades, como esencialidades creadas y moldeadas por los poderes coloniales y remodeladas por las nuevas formas de colonización, son releídas y transformadas desde prácticas de concienciación, como la "nueva novela histórica". Algunos ejes en la novela Laberintos de orgullo son muestra de cómo ha leído la nueva novela histórica la conformación de las identidades centroamericanas.

\section{AUTORA - NARRADORA: EL CONTROL DEL SENTIDO}

Desde una perspectiva foucaultiana, Amoretti (2002) explica que entre las categorías literarias más sólidas y constantes a lo largo de la historia están la de autor y la de obra, categorías que en la "nueva novela histórica" asoman desde las primeras líneas. El autor es una instancia intra - extra textual que controla el sentido del escrito y, al mismo tiempo, asume la responsabilidad de su enunciado, lo cual coincide con sus acciones y cualificaciones.

Por lo general, en el subgénero, el autor asume su dicho desde los paratextos, en los prólogos y cierra la novela con algún epílogo, explicación o coda, donde deja claro para los lectores que en todo momento la producción literaria ha surgido de su investigación y de su escritura. Es sorprendente que en más de un 95\% de los casos, el autor - narrador se erige como figura autorizada que ordena el mundo, lo reglamenta y se sirve de la metaficción para guiar la lectura.

A veces, el autor - narrador se construye gradualmente $y$ entonces el narrador omnisciente le sirve como "médium": lo va nombrando, construyendo, por medio 
de alusiones e indicios, hasta que deja ver su nombre, en el que se anudan las significaciones. En el juego de las identificaciones, el autor - narrador es él y no lo es, a lo que es contrapone lo que quiere ser. Pero el sentido más relevante que se le confiere al autor - narrador es la red de discursos que genera como sujeto, quien puede hablar y darle sentido a su propio mundo.

También el autor - narrador es un pilar de la identidad, porque aglutina en sí toda una constelación figurativa relacionada con un mundo posible - el mejor mundo posible, según Foucault-, en cuya constitución entran los diferentes niveles textuales. El autor - narrador es un yo que pone en escena un ideal de pueblo, de persona, de intelectual, sostenido por una axiología moral. La actuación en el gran escenario textual obedece a un guión que el autor - narrador monta a partir de una lectura que oscila entre el estereotipo, lo establecido, la frase hecha y la transgresión. De su enunciado interesan, precisamente, esas zonas de quiebre, donde se manifiesta en toda su magnitud.

El autor - narrador le confiere un sentido específico al arte en general y, específicamente a la literatura en especial, por medio del recurso de la metaficción, tantas veces señalado por la crítica. Gracias a esa estrategia textual es posible que el texto se vuelva sobre sí para cuestionar su condición, concepciones y funciones y que el autor - narrador se autoasigne un lugar en el mundo mostrado.

En Laberintos de orgullo, la autora abre el texto en la "Breve explicación histórica a manera de prólogo"; en ese paratexto la autora, Rosa María Britton, se encarga de relacionar la novela con su propia vida. Cuenta que su madre le relató la historia de la llegada de Leopoldo III de Bélgica a Panamá, en busca de la ruta de Balboa, y que esa historia marcó su vida; lo más sorprendente fue saber que un rey europeo, quien compartió unos pocos días con su madre, jugara billar con los nativos. A raíz de esa anécdota se dio a la tarea de investigar la vida del monarca y, por supuesto, de ahí surgió la idea de escribir la novela.

Aclara también Britton que los personajes históricos como Torrijos, Noriega, Spadafora y otros a los que ella llama "secuaces, compinches, bellacos, oportunistas que contribuyeron a esta triste historia, son de todos conocidos" (p.12). Por otra parte, se atribuye y responsabiliza por la interpretación que ha hecho del momento histórico en el que viven esos personajes, "y por ello no pido disculpas" (p.12).
Una de las más notorias coincidencias entre la autora y el personaje de Irina Conde es que ambas son psiquiatras. No se puede dejar de relacionar durante la lectura a la primera con la segunda. Irina escucha, en su condición profesional médica, el relato de Santos; es decir, el relato que incluye todos los otros relatos; pero es Irina la que da la interpretación. Al menos eso es lo que se esperaría de una lectura médica. Al final Irina cae en la confusión, pues se ha enamorado de Santos y, en algunos momentos, él la interroga sobre su condición de médica, de mujer y de intelectual.

El "Epílogo" (p. 531) es en realidad el "Diario de Irina Conde". En él, la psiquiatra ha anotado el caso clínico de Santos, que es la historia de un enfermo mental, y trata de saber la causa de su enfermedad'. En algún momento empieza ver un parecido de Santos con su propio padre y así, la historia de ambos se va entrelazando. Además, ella se involucra sentimentalmente con su paciente.

La relación entre la enfermedad y la función de la autora - narradora trasciende el estatus de psiquiatra de ella: la enfermedad surge de un conflicto no resuelto sobre su identidad, y en sus orígenes está la causa del mal cardíaco. El corazón es simbólico: su vida está llena de dolor por haber perdido a los seres que más amaba, a su madre y a Luz María. Eso había provocado que su vida se hubiera dedicado a la búsqueda de su madre $y$, al menos, a saber de dónde era su padre.

La autora - narradora ha asumido, en su doble condición intra y extra literaria, la misión de tratar una enfermedad que ha surgido de la mente, de no saber quién es; no obstante, en las confesiones del diario médico evidencia que ella también padece una enfermedad similar y, en la medida en que escribe todo lo que Santos le ha confesado, va escribiendo también su historia. Asocia los actos y pensamientos de la vida del otro a los suyos. De manera que la tarea de Irina resulta ser la de "curar", darle una respuesta a la encrucijada, buscar la salida del "laberinto" de su propia existencia.

De sus intentos por descifrar el misterio de la enfermedad de Santos arriba a la conclusión de que Misaela, la madre de Santos, "es la clave del enigma de este hombre" (p.541). Misaela es el centro integrador de su familia disfuncional y, por lo tanto, de una idea de nación, como se explicará más adelante.

La reformulación de las imágenes nacionales y la interpretación histórica que hace la autora - narradora le confieren a la novela un carácter de texto de 
recuperación de la memoria histórica, así como de reflexión sobre la forma en que esa historia se ha escrito.

Una misión de esa magnitud solo puede ser emprendida por una figura de peso; por esa razón, la autora - narradora se construye como una intelectual de una clase que es aludida en la novela porque ha olvidado su lugar en la historia y su capacidad para transformar las condiciones de su país. Irina Conde es médica y en la medida en que se identifica con la autora, es también escritora.

Santos no logra percibir la corrupción y el entreguismo de sus gobernantes, así como tampoco es capaz de interpretar su pasado y encontrar a su madre, sino hasta que va a Europa a estudiar y regresa convertido en un economista. A él se suman personajes como estudiantes y artistas, quienes se oponen a los burgueses inconscientes, como Patricia y su familia, descendientes de las familias fundadoras de Panamá, ahora ajenas a su pasado.

La crítica se extiende a los intelectuales, a poetas oportunistas y políticos que han vendido sus principios a la dictadura militar de turno o a los Estados Unidos. Todos ellos son el reverso de la figura de Roberto, el amigo que lucha en las calles de Panamá y es herido por las balas por defender a su país de la opresión.

La construcción de la instancia autorial como una voz intelectual funciona en la novela, como se explicó en los primeros párrafos de este apartado, como un foco de la interpretación de los sentidos. Señala Amoretti (2002) que la imagen autorial es:

Un efecto y una función del propio discurso (...), pero coproducido al mismo tiempo por el funcionamiento del texto dentro de una práctica (institucionalizada), es decir, del hecho de que ese discurso escrito se pone a circular según determinados mecanismos sociales que regulan no solo su modo de producción, sino también su modo de distribución y consumo (p. 47).

Como función textual, la autora - narradora de Laberintos de Orgullo es el centro integrador de la propuesta identitaria del texto. Su proyecto es conocer la historia de Santos, una historia familiar y política y ofrecer una propuesta esperanzadora. En este último aspecto la "nueva novela histórica se distancia de otras tendencias contemporáneas clasificadas como literatura del desencanto o del cinismo. En ese sentido, Irina expresa:
Puedo darme por satisfecha, he logrado que mi paciente, a pesar de su enfermedad, salga de la depresión y contemple el futuro con esperanzas (...). Además, ¿para qué seguir engañándome? Me interesa demasiado conocer la historia que no acabó de contarme; necesito ser parte del resto de esa vida, de los días, por muy pocos que sean, de un hombre llamado Santos Calderón. (p. 546).

La función autorial de esta novela no se diferencia mucho de la de la novela tradicional: el yo es una autoridad cultural que habla en nombre de una comunidad con la cual se identifica; es, además, una voz elegida para educar, enseñar y concienciar al lector. Sin embargo, la red de discursos que reúne en sí la instancia autorial se relaciona en el juego de la afirmación y la transgresión y cada constante discursiva es un hilo en la propuesta de mundo.

A continuación se analizarán los ejes organizados en torno de la voz autorial.

\section{LA FAMILIA, LA NACIÓN}

La "nueva novela histórica" presenta un eje de identidad familiar muy recurrente y ligado a cronotopos como el de la casa; sin embargo, no se trata de la identificación familia - nación estructurada por los discursos nacionales. Lejos de la representación armónica e idealizada de la familia, la imagen original se ha resquebrajado.

Como metáfora nacional, la imagen familiar no es nueva. Ovares, Rojas, Carballo y Santander (1993), hacen una afirmación que resulta válida para las novelas leídas para este trabajo, entre las cuales se encuentra la estudiada aquí: "no existe una conciencia nacional previa e independiente de los textos y la retórica que la construyen y expresan" (p.3). En otras palabras, los textos periodísticos, políticos, críticos, historiográficos y artísticos, entre otros, construyen en conjunto la idea de nación, la formación discursiva que engloba, en última instancia, las imágenes nacionales desde la ideología patriarcal: "La homología central del discurso nacional, es decir, nación = familia, alude al tipo de relaciones que deberían existir idealmente, tanto en una como en otra: armonía, ausencia de conflictos, origen común y respeto a la autoridad y al orden" (Ovares, Rojas, Carballo y Santander,1993).

En Laberintos de orgullo la familia de Santos rompe con la imagen de la familia - nación, porque es una 
familia disfuncional, las relaciones son conflictivas o faltan miembros de la familia. El hijastro, Santos, deja morir al padrastro, no sabe quién es su padre y el pasado de la madre es un misterio. Después la madre desaparece y la busca en Colombia; ahí encuentra a su abuela materna y a sus tíos, así como la verdad en relación con su progenitor. Llega a saber que tiene una hermana que no lo acepta. Sus hermanos, hijos de su madre y su padrastro Zambrano, tampoco lo quieren y cuando crece él no quiere saber nada de ellos. Fenotípicamente son muy diferentes: Santos es blanco, casi rubio, y ellos tienen rasgos afrodescendientes.

Estas relaciones en la trama, en el nivel de las significaciones familiares, se relacionan con el concepto de nacionalidad panameña, estructurada como un conflicto familiar; pues Santos, un niño panameño, despreciado por los habitantes de Chumico porque es un niño blanco, desde muy pequeño se propone buscar el misterio de su propio ser. No logra reestructurar a su familia hasta que junta todas las partes del rompecabezas y acepta, dejando de lado su "orgullo", que su familia es diversa en todo sentido. El viaje a Colombia, la muerte de Luz María y la amistad de Roberto le hacen ver quién es él. A partir del momento en que acepta su pasado empieza a tener esperanza en el futuro.

Otros personajes le van recordando que tiene unos hermanos afrodescendientes, una madre colombiana, un padre también colombiano, pero que lo abandonó y - un elemento que lo amarra con Panamá - doña Catalina, su madrina, llega a sustituir a la madre. Ella representa la "madre patria", España, otra parte de sí que llega a aceptar. Este elemento también se representa en la figura de Leopoldo III, una especie de reencarnación de Balboa. Esta es la verdadera familia de Santos: diversa, plural. Así la recompone para sanar de su enfermedad y para tener un futuro.

En cuanto a la vida de Misaela, ella es una imagen nuclear de la metáfora familiar. La autora expresa, en la "Breve explicación histórica a manera de prólogo", que "Misaela Calderón, su historia y el lugar en que se desarrolla, son también producto de mi imaginación" (p. 12). La gente del pueblo de Chumico no perdona a Misaela por su origen colombiano, pero al final Santos la reivindica. Ella había llegdo del Chocó embarazada, lo había dado a luz en la selva y llegó a Chumico con él en brazos.

Para lograr la recomposición de la imagen familiar, Santos tiene considerar la imagen de la esposa, Patricia. La amiga y amante, Luz María, posee atributos crísti- cos, conciencia social y entrega al pueblo, mientras que Patricia es una mujer de la alta burguesía panameña, superficial y entregada al consumismo. Realiza constantes viajes a Europa y a los Estados Unidos, país que representa para ella un ideal. Ahí estudian sus hijos, a los que aleja de sí dejándolos en un internado por años. Esta es una variante también disfuncional de la familia. A Santos y a Patricia los une el interés:

A mi madre la quise mucho y ahora es mi hija la que llena de ternura mi corazón. Al resto de la familia me une el parentesco, la fuerza de la costumbre, el mutuo interés, mi mujer y mi hijo viven pedientes hasta del último centavo que poseo, la codicia es un poderoso sentimiento que mantiene a muchas familias unidad hasta el final (pp.44).

Las clases altas, personificadas por Patricia y su familia, son aludidas en esta novela como capaces de cambiar el rumbo del destino de la nación, pero están entregadas a la codicia y no tienen interés de cambiar nada.

La nueva burguesía a la que pertenece Patricia se presenta como degradada frente a una clase que es mirada con nostalgia: la vieja aristocracia. Catalina personifica esa clase; gracias a ella Santos puede estudiar y superarse. Doña Catita, como se dijo antes, es también una figura materna asociada a los antiguos valores morales y patrios, integrante de la familia, por eso se mira con nostalgia, así como a la antigua casona y a las prácticas ancestrales como la conversación:

Esa misma tarde, lo llevó a la casona de calle primera, ubicada muy cerca del Club Unión, centro vital de la aristocracia de la ciudad. La señorita Catalina los recibió cordialmente, levantando una mirada inquisitiva hacia Carmelita al asombrarse nuevamente del aspecto de Santos (...). Por su posición social, hija de un prócer de la independencia y dueña de una vasta fortuna, muchos la visitaban y cada tarde recibía de cuatro a seis a cuantos quisieran venir sin anunciarse. En la casa no había teléfono ya que a doña Catita le disgustaba el aparato, considerándolo una intrusión en su vida privada manifestando a cuantos trataron de convencerla que adquiriera uno que no estaba dispuesta a escuchar timbrazos a todas horas. - Bell es el responsable de la muerte de las relaciones humanas directas y la tertulia erudita (p.153). 
La comunicación cara a cara se ha ido perdiendo y doña Catita se lamenta por la pérdida de los lazos que unían a la familia, a la gente de su país, que ahora no tiene mucho que compartir.

La anciana encarna lo que ha quedado de la herencia europea. En este y en otras novelas de la misma clase, el componente europeo, especialmente español, es recuperado positivamente frente a la imagen de los Estados Unidos, nación a la que se le atribuye, en buena medida la desintegración de la familia y la pérdida de la identidad. Pero la imagen de los Estados Unidos como pueblo es positiva, como en el caso de George, un gran amigo que acude al Ilamado de Santos en todo momento. Los Estados Unidos como imperio son vistos en el sentido de atribución de causalidad de la opresión del pueblo panameño.

De modo que la imagen familiar como metáfora nacional no se pierde en la novela contemporánea, al menos en "la nueva novela histórica", pero sí se reconstruye a partir de la diversidad, la heterogeneidad y la pluralidad: europeos, afrodescendientes, colombianos y centroamericanos (con clara mención de Costa Rica).

Otro eje en la construcción de la identidad en Laberintos de orgullo es el eje espacio temporal, el que articula los acontecimientos y personajes, el presente y el pasado como foco histórico y, en última instancia, identifica las determinaciones genéricas: "el cronotopo de Indias".

\section{"EL CRONOTOPO DE INDIAS" EN LA CONSTRUCCIÓN DE LA MEMORIA HISTÓRICA}

El acontecimiento que en 1953 cambió la vida de Santos, siendo aún un niño, fue la llegada de Leopoldo III, de Bélgica, a Chumico. No solo el hecho de relacionarse con un rey, ayudarlo a curarse de una enfermedad gracias al conocimiento del uso de las yerbas medicinales que le enseñó su madre, sino que ese rey siguiera el camino de Balboa para descubrir el Mar del Sur y le permitiera recorrer con él la ruta del gran conquistador, fue el medio por el cual Santos logró unir el pasado con el presente, en una relación de continuidad de más de cinco siglos.

Uno de los temas más tratados por la "nueva novela histórica" es el de la conquista, con el cual se espera encontrar las respuestas a la forma de ser de los latinoamericanos, centroamericanos y panameños, su origen y la causa de sus rasgos. Sin el pasado, el presente no se puede explicar. La conquista conduce, entonces, a un punto de anclaje histórico fundacional de la identidad, recuperado por la memoria histórica, función que se arroga la "nueva novela histórica": reflexión sobre el pasado como lección del presente y proyección de los posibles futuros. Contrario sensu, el olvido es "esas angustias", germen de su depresión y enfermedad cardíaca:

Tendré que exprimir la memoria, pero no le garantizo exactitud. Imagino que usted tampoco es capaz de recordar lo que pasó el primer día que fue a la escuela, ni la primera vez que sintió una cólera asombrosamente ausente de toda lógica, capaz de convertirla en un ser irracional. No, no lo niegue, doctora. Todos pasamos por esas angustias si uno tiene sangre en las venas, todos, aunque la memoria se empeñe en borrar los hechos desagradables y nuestra vanidad intente mostrarnos como lo que realmente no somos. (Brittton, 2002, pp. 15-16).

La presencia de Balboa conecta a Santos con el pasado de la conquista y la colonia, donde se origina el conflicto de su identidad. Este episodio histórico aparece en gran parte de las novelas del subgénero con el mismo significado. Para Iris Zavala (1993) el encuentro de cronotopos (visiones de mundo occidentales y visiones precolombinas) dio lugar a diversas expresiones de la otredad y de lo que se llamó "Nuevo Mundo". Esa heterocronía deriva nuevas relaciones e imágenes en el presente, pero siempre determinadas por "el cronotopo de Indias":

Una tiranía de la visión tiene su origen en este encuentro, cuando una sociedad moderna (la España europea imperial) despliega una forma panóptica en tanto forma emergente de vigilancia de las sociedades disciplinarias. Una taxonomía que atribuyó series globales de valores sobre una base ética y moral (mejor - inferior, bueno - malo) caracterizaba una óptica parecida ya que el observador cataloga cada pequeño detalle de los ciudadanos del Nuevo Mundo. La panóptica inaugurada por Colón fue regularizada como emblema de vigilancia y de diferenciación de individuos y llegó a convertirse en el estandarte de una homología civilizante y cristianizante. Las formas del poder encarnadas en las lenguas especializadas e institucionalizadas estaban en la base de la lógica de correlación de cronotopos (el saber, 
el poder y el lenguaje) que allí participaban (Zavala, 1993, p.6).

La autora - narradora - médica remodela el mundo del cronotopo de Indias desde su perspectiva para construir una imagen nacional, que aunque se halla cohesionada por el referente familiar y la lógica de correlación cronotópica (la intelectualidad, el poder y la lengua española), revisa cada uno de los fragmentos de ese cronotopo para devolverlo transformado de acuerdo con el presente. El cronotopo de Indias se lee en esta novela de manera invertida: de lo homogéneo y unitario a la pluralidad, de la "pureza de sangre" a la variedad étnica, y de esa inversión, frente a la cultura occidental emergen las culturas.

Laberintos de orgullo plantea, junto con la producción total de la "nueva novela histórica" de Centroamérica, una teoría de la multiculturalidad y solo desde ahí es posible la inserción de Santos en su mundo, en su país, sin conflictos. Su mirada reflexiva va estableciendo una nueva cartografía de Indias; por esa razón retoma el camino de Balboa y solo cuando viaja a Europa reconoce que debe regresar y recuperar a su madre.

Otro cronotopo asociado con el de Indias es el que se deriva de la división física y política causada por la construcción del Canal de Panamá. Este es un referente obligado en el imaginario panameño y se asocia con una nueva conquista por un imperio actual, los Estados Unidos. Aquí el cronotopo del viaje sirve para que Santos conozca su país y su realidad, ve con sus propios ojos, lo cual es un criterio de verdad sin la mediación del discurso historiográfico. Cuando viaja de Chumico a la ciudad recorre las calles con Luisito, su amigo. Se desplaza por todos los lugares importantes que siempre recordará y que en el futuro, una vez convertidos en suburbios y locales comerciales, va a extrañar. En su deambular, los dos niños llegan hasta la entrada a la Zona del Canal, donde un policía les cierra el paso:

-Pero, ¿acaso está prohibido andar por ese lugar?

-Bueno, si le notan a uno cara de pobre y panameño, enseguida llueven los palos.

-Si le ven a uno cara de negro y pobre- interrumpió Clotilde. (...) otros se quejaban de la odiosa discriminación en contra de los nacionales, pérdida de soberanía, viejos conflictos y heridas que no cerraban. Todo lo quería aprender en poco tiempo (p.96).
La ciudad le muestra a Santos "un país dividido en dos" y lo lleva a descubrir que nunca alcanzará sus sueños en el pequeño pueblo de Chumico, pues la urbe sigue siendo un espacio ambiguo: es el lugar de la perdición y, al mismo tiempo, ahí está lo moderno, el progreso, la entrada a la vida cosmopolita.

Una constante discursiva más asociada con la identidad y producida por la reelaboración del "cronotopo de Indias" es la propuesta política, cultural y estética de esta y, en general, la "nueva novela histórica".

\section{PROPUESTA POLÍTICA Y LITERARIA}

En este aspecto también es clave la figura de la autora - narradora porque se autoconstruye como un modelo de heroína, la intelectual que ha desplazado la figura del guerrillero. En la "nueva novela histórica" el militante de la revolución ya no representa ninguna solución. Un ejemplo de esto se manifiesta en la novela Got seif de Cuin! (1995), del escritor beliceño David Ruiz Puga, donde el prototipo de revolucionario es Gandhi. En Laberintos de orgullo (2002) la lucha armada es un último recurso:

Pero bueno, así son los pueblos, exigen sangre para alimentar esa vanidad Ilamada gloria, cuando la verdadera sabiduría está en retirarse a tiempo de situaciones que no podemos controlar y saber que la vida es una sola y no se recupera. Se pelea hasta la muerte cuando no existe otra opción, pero si hay otro camino, es preferible escogerlo, antes de perecer. ¿ $\mathrm{No}$ le parece que tengo razón, doctora? (p. 71).

Castigada por interminables revoluciones, Centroamérica hace su propia propuesta de mundo desde la "nueva novela histórica". Las ideologías que animaron las luchas armadas se desechan para dar paso a un tipo de revolución que llevan a cabo los intelectuales; se trata de una revolución del pensamiento, por eso se da la fuerte apelación a los pensadores, escritores, filósofos y otros que coinciden con los autores - narradores personajes.

Las nuevas guerras son mucho más difíciles de pelear, según lo plantean las novelas, porque las armas enemigas y las estrategias de dominación son sutiles y están en todo momento bombardeando las mentes con sus mensajes e imágenes, con sus modelos de seres humanos que nada tienen que ver con los valores propios. 
Esta perspectiva es la que engrandece la figura del intelectual, de la instancia autorial, pues solo la educación puede salvar al pueblo del influjo alienante del gran imperio norteamericano. Leopoldo III se lo hace ver a Santos²:

-Y dígame, joven amigo, ¿qué piensa hacer al terminar su carrera?

- Voy a dedicarme al mercado de valores, las finanzas- alcanzó a decir.

- Me parece bien, esa es la carrera del futuro. Solamente le aconsejo que siempre tenga presente el bienestar de su gente; es importante que pase lo que pase nunca se arrepienta de sus acciones si son correctas, ni se deje amedrentar por nadie a pesar de los obstáculos que pueda encontrar en su camino, y encontrará muchos ... Nos pasa a todos (p. 201).

La clave de esta propuesta pacifista está en vivir en paz en la diversidad. La nación pierde así su carácter monológico. Está conformada por varias culturas que se interrelacionan, pero que preservan sus formas de vida y las transmiten las generaciones más recientes.

En cuanto a la propuesta literaria, se deduce del papel del intelectual y del artista que presentan las nuevas novelas históricas, en sus autores, que la novela es un espacio de reflexión donde se replantean los paradigmas históricos y artísticos. Asimismo, es un espacio combativo de transformación de las mentalidades. Los planos filosófico y artístico cobran relieve en esta modalidad literaria. Ahora la literatura sirve para denunciar, criticar y reescribir, más importante aún, señala que el futuro puede construirse como una posibilidad más entre otras, desde la literatura. Vistos así la función de la literatura y el papel del escritor, asoma el discurso arielista: el escritor es un mentor destinado a educar a un pueblo ignorante.

En ese escenario ¿cuáles son los rasgos de la autoimagen del panameño que se manifiestan en la novela Laberintos de orgullo"?

\section{AUTOIMÁGENES DE LA IDENTIDAD}

La conciencia de la propia imagen está dada por una serie de rasgos negativos y positivos. Ya se mencionaron la enfermedad y la disfuncionalidad como atributos de la identidad del panameño. A ellos la autora - narradora opone la aceptación del origen y de la multiculturalidad, todo por medio de una acción educativa.
Aunque en Laberintos de orgullo hay valores del panameño que son muy positivos, como la solidaridad y el trabajo, el pueblo padece un gran mal que ha causado todos los sufrimientos que experimenta: la falta de conciencia histórica: "estaban convencidos de que la memoria histórica de los pueblos es débil" (p.309). Esta es uno de los aspectos más criticados por la "nueva novela histórica" en general. Santos hace referencia a la efervescencia que se vivía en los días de Noriega, a la muerte de Spadafora y a los problemas que la ciudadanía padece por causa del olvido de sus orígenes, de su condición en el mundo y, principalmente, de su historia:

Aunque parezca mentira, era lo único que les preocupaba a muchos en esos días, que ahora se hacen pasar por grandes patriotas y este pueblo, que padece de amnesia colectiva, ya no recuerda quién hizo qué o quién no hizo nada. Abstenerse de protestar una injusticia es el peor de los pecados; me he acusado durante años sin encontrar la absolución ni confesarme con nadie (pp. 440 - 441).

El pueblo también presenta otras debilidades que la escritura literaria en su función concienciadora pretende transformar; por ejemplo, Santos pensó que "a su mujer solamente le interesaba el status quo, su lugar en esa sociedad que parecía agonizar por falta de lealtades" (p. 393). A la deslealtad se le suma la "actitud de avestruz; es mejor meter la cabeza en la arena".

Los personajes que representan diferentes sectores de la población de las clases más bajas o de los pueblos costeros se desenvuelven a considerable distancia del lugar de la autora - narradora, pero es necesario escuchar su rumor porque expresan el contradiscurso del poder. Se trata de beatas chismosas y supersticiosas o de "negros confianzudos", entre otros. Es la voz colectiva que no se sabe de dónde sale, que denuncia y que tanto intranquiliza al dictador. En la propuesta de mundo de la novela, a ese rumor se le confiere un gran poder, que los mismos grupos desconocen. Solo la memoria histórica devuelta por la novela y la educación puede concederle a los diferentes grupos de la nación panameña su lugar en el poder.

En la construcción de la propuesta de identidad de la novela está el rescate de la herencia española, como ya se dijo. Balboa es el sostén de esa imagen: "La sombra de Balboa envolvió a todo el pueblo, unos días verdaderamente gloriosos" (p. 77). En Balboa se sintetizan una lengua, una geografía, un legado 
genético y cultural que, según la propuesta novelesca, debe ser preservado, al tiempo que se vive en el mundo de la mundialización de la cultura.

En los mapas de la identidad de Laberintos de orguIlo, el paisaje panameño es descrito con detalles porque por medio de esas descripciones se afirma que el paraíso perdido está "aquí". No es necesario ir, como lo hace Patricia, a Europa o lo Estados Unidos para encontrarlo o para buscar referentes de sí.

Un último eje discursivo de la formación de la identidad se impone: la construcción de la identidad femenina.

\section{LAS MUJERES EN EL LABERINTO}

Son muy pocas las nuevas novelas históricas que se interesan por la condición de las mujeres. Por el contrario, algunas mantienen estereotipos femeninos. Entre las pocas que hacen una lectura desde la perspectiva de género está Laberintos de orgullo. La autora - narradora revela que es una novela escrita con conciencia de la condición de mujer de su autora. Para Ciplijauskaité (1996: 36) cuando se habla de novela de concienciación se trata de "la novela femenina de nuestro tiempo: va desde una escritura que tiene asomos de testimonio, de realismo y de crítica social, es decir, muy bien integrada en el contexto, hacia la investigación interior" (p. 36).

De acuerdo con las características que señala Ciplijauskaité para la novela de concienciación, Laberintos de orgullo cumple con los requisitos: es escritura de autoconocimiento, de memoria y de crítica al lugar de la mujer. Además, integra a la mujer en la construcción de la subjetividad.

Para empezar, la instancia autorial se define como femenina. Aunque Santos es el protagonista de la novela, es Irina Conde quien asume e interpreta su confesión y, en consecuencia, su historia. Por otra parte, como ya se apuntó, la clave de la vida de Santos está en Misaela, su madre. Todos los trayectos de la vida del protagonista están determinados por una mujer. Ellas son las que lo sacan del "laberinto de su orgullo" y de los laberintos de su pasado, porque le dan sentido a su vida.

Como sucesora de la madre de Santos aparece la hija de él, Misaela, con el mismo nombre de la abuela e idéntica a ella, por eso Santos la ama profundamente. A la hija la llaman Misi y ella salva a Santos en los peores momentos de soledad.
Misaela, la mamá de Santos, no solo personifica a la nación, sino que también constituye el prototipo de la madre: abnegada, sufrida, sacrificada. Además, ha sufrido mucho en manos de un hombre agresivo, el padrastro Zambrano. Huye a Colombia para no perjudicar al hijo. En casa de su familia muere de cáncer. Como el único medio para descifrar su propio enigma, Santos la busca incansablemente hasta encontrarla en sus últimos días. Apenas tiene tiempo para decirle cuánto la ama y contarle sus triunfos.

La otra figura materna, que también representa la nación y le cambia el destino a Santos es doña Catalina. Ella lo protege, lo cuida y completa la misión de Misaela cuando le proporciona a Santos la oportunidad y los medios para que estudie y triunfe. Ella le da educación, uno de los valores que más prestigia la "nueva novela histórica".

Luz María y Patricia se contraponen a lo largo de toda la novela y la oposición entre ambas enfrenta dos tipos de mujer. La primera es la amante y amada. Santos la ha querido toda su vida. Aunque nace en un hogar de aristócratas, es "buena esposa" y madre, ella evoluciona hacia la superación de todos los estereotipos. La segunda es también hija de familia aristócrata, pero no sufre ninguna transformación. Se identifica plenamente con los modelos femeninos tradicionales: esposa y madre abnegada. Soporta un matrimonio por conveniencia para beneficiar las finanzas de sus padres. Ella es superficial, materialista y vive de las apariencias. Actúa de acuerdo con conceptos caducos de honra femenina.

Cuando Santos decide amar a Luz María está aceptando todo lo que ella representa. Luz María sale a las calles a luchar por la libertad de su país. La resolución textual la ubica peleando hombro a hombro con Santos y Roberto. El amor de Luz María es intenso y espontáneo y los encuentros con Santos funcionan como una forma de conocerse.

La figura de Luz María por su parte, es una propuesta de mujer independiente, valiente, decidida y libre. Respeta, ama. También es madre y llora por la muerte de su hija Mariluz, quien había enfermado psicológicamente por causa de la infidelidad y el abandono del padre (otra forma de desarticulación de la familia tradicional). En su representación de la mujer ideal, a Luz María la asesina un maniático, personificación del más extremo patriarcalismo: un militar que tiene el apodo "Demonio de Tazmania". 
Hay otros personajes femeninos de menor relieve en el texto. Aparecen en forma colectiva o con menos participación. Entre ellos están las mujeres del campo, coterráneas de Misaela, quienes aún viven en un sistema feudal y son propiedad del dueño de las tierras, como lo fue Misaela:

Un vago resentimiento le va llenando el pecho, entiende claramente el objetivo de don Migue, el dueño de la vida de todos los que habitan en el valle. Es él quien compra las cosechas y a buen precio -en cuestiones de negocios es legal-, el señor que dispone de la honra de todas las mujeres y lleva en el pecho la marca de cuanta mujer ha desflorado, el señor feudal con derecho a pernada (p. 104).

Don Migue reitera los rasgos del militar asesino y a ellos se oponen Roberto y Santos. Los dos últimos son verdaderos amigos, leales y respetuosos. Encarnan un ideal de hombre construido desde la óptica femenina: a la misma estatura que las mujeres de su vida. Este planteamiento de mujer y de hombre solo tiene cabida en la propuesta de multiculturalidad que se desarrolla en la misma novela, ajena a cualquier jerarquía.

\section{CONCLUSIONES}

El análisis de algunos de los ejes que sustentan las propuestas identitarias de la "nueva novela histórica" en Laberintos de orgullo, de Rosa María Britton, ha permitido visualizar las condiciones de producción de un sugénero novelesco de un ciclo largo.

Por su relación particular entre la historia y la ficción, este tipo de novela ha contribuido con la reformulación de los paradigmas epistemológicos y, por tanto, artísticos, filosóficos e históricos.

En la novela analizada como muestra es posible percibir que los imaginarios nacionales han sufrido profundas transformaciones, como en el caso de la metáfora familia - Nación. Este núcleo de la red de significaciones de la nacionalidad se abre a la inclusión de los grupos que ni geográfica ni étnicamente formaron parte de las naciones. No es que la familia nacional se destruya, sino que busca recuperar los nexos familiares mediante el reconocimiento de los parientes invisibles: afrodescendientes, mujeres, indígenas; o de los parientes con los cuales se ha tenido conflictos por el poder: los ancestros de origen europeo.
Se ha arribado también a la conclusión de que la "nueva novela histórica" comparte con la novela histórica tradicional el hecho de volver la mirada hacia eventos y personajes históricos, pero se diferencia de ese tipo de novela histórica porque asume la pérdida de significado del relato histórico. El pasado se va perdiendo de la memoria de las personas del presente. Asimismo, darle sentido a los procesos históricos es necesario para conferirle también significado al futuro.

\section{NOTAS}

1 La enfermedad es un tema recurrente en la literatura latinoamericana, desde sus inicios. En la "nueva novela histórica el asunto también aparece con mucha frecuencia; por ejemplo, se tiene la enfermedad de Pedrarias Dávila en Réquiem en Castilla del Oro; el padre que mantiene atado al hijo por causa de su enfermedad, en El pasado es un extraño país; el padecimiento de Orlandus, en Limón Blues, de Anacristina Rossi. La lista de ejemplos es interminable.

2 En ese momento Santos es estudiante de economía en Bélgica. En este diálogo participan un personaje histórico y un personaje ficticio. El personaje histórico permanece igual al ideal que se tiene de él, en toda la novela; el personaje ficticio evoluciona hacia un ideal de ser humano.

\section{REFERENCIAS BIBLIOGRÁFICAS}

Amoretti, M. (2002). La irresistible seducción del discurso. San José: Editorial Perro Azul.

Anderson, B. (1983). Comunidades imaginadas. Reflexiones sobre el origen y la difusión del nacionalismo. México: Fondo de Cultura Económica.

Arias, A. Gestos ceremoniales. Narrativa centroamericana. 1960 - 1990. Guatemala: Editorial Artemis - Edinter.

Augé, M. (1994). Los "no lugares". Espacios del anonimato. Una antropología de la sobremodernidad. Barcelona: Editorial Gedisa.

Bajtin, M. (1989). Teoría y estética de la novela. Madrid, Taurus.

Britton, R. M. (2002). Laberintos de orgullo. Panamá: Alfaguara.

Ciplijauskaité, B. (1996). La novela femenina contemporánea (1970 - 1985). Hacia una tipología de la narración en primera persona. Barcelona: Editorial Anthropos. 
Mackenbach, W. (2004) ¿La nueva narrativa centroamericana: una literatura de posregionalismo? 82004). Revista Istmo, núm. 8. Descargado el 2 de mayo de 2013 desde http: // collaborations. Denison.edu/istmo/n08/articulos/pos-ismos.html.

Menton, S. (1993). La nueva novela histórica de América Latina, 1979 - 1992. México: Fondo de Cultura Económica.

Ovares, F., Rojas, M., Carballo, M. E. y Santander, C. (1993). La casa paterna. Escritura y nación en Costa Rica. San José: EUCR.

Ruiz Puga, D. (1995). Got seif de Cuin! Guatemala: Editorial Nueva Narraativa.
Vargas, J. Á. (2004) Novela centroamericana contemporánea y ficcionalización de la historia. Revista Comunicación (13), núm. 1, 5 - 16.

Zavala, I. (1993). Romanticismo y realismo (historia y critica de la literatura española. Barcelona: Editorial Crítica.

Zavala, M. (1990). La nueva novela centroamericana. Estudio de las tendencias más relevantes del género a la luz de diez novelas del período 1970-1985. Disertación no publicada para optar por el grado de Doctora en Literatura. Université Catholique de Louvain. Bélgica: Universidad Católica de Lovaina. 